\title{
TOTAL LIPIDS AND FATTY ACIDS OF STRAINS OF METARHIZIUM ANISOPLIAE
}

\author{
Antonio Marcos Pupin²; Claudio Luiz Messias ${ }^{1 *}$; Aquiles Eugênico Piedrabuena ${ }^{1}$; Donald Wilson Roberts ${ }^{3}$ \\ ${ }^{1}$ Departamento de Genética e Evolução, Instituto de Biologia, UNICAMP, Campinas, SP, Brasil; ${ }^{2}$ Centro de Pesquisas \\ Químicas, Biológicas e Agrícolas-CPQBA, UNICAMP, Paulínia, SP, Brasil; ${ }^{3}$ Department of Biology, Utah State University \\ Logan, Utah, USA
}

Submitted: December 12, 1997; Returned to authors for corrections: June 02, 1998; Approved: June 26, 2000

\begin{abstract}
Two growth stages, conidia (C) and mycelium (M), and two media, minimal medium (MM) and complete medium (MC), were compared in 10 strains of $M$. anisopliae, and two strains of M. anisopliae var. majus were similar in percentages of total lipids. Tukey test for average of lipid content in conidia (C) and mycelia (M) cultured on minimal (MM) and complete (MC) media showed significant differences between means at the 5\% level for mycelia and conidia, indicating variability in total lipid production and storage during growth. Strains 5 and 7, both variety majus, did not present sizable differences from variety anisopliae. For fatty acids, C18:1 and C18:2, oleic and linoleic, respectively, the differences were all highly significant ( $\mathrm{p}=$ $1 \%$ ) with the highest means being obtained for conidia for fatty acid C18:1 and for myclelia for fatty acid C18:2.
\end{abstract}

Key words: lipids, fatty acids, Metarhizium anisopliae, entomopathogenic fungi, microbial control

\section{INTRODUCTION}

The fungus Metarhizium anisopliae has been used in Brazil in programs aiming at the microbial control of agricultural pests, in particular Mahanarva posticata (Homoptera: Cercopidae), the sugar cane leaf spittlebug (12), and for the control of other pests in different countries (18).

Lipids are important fungal components both in terms of structure and membrane constitution. Many studies have demonstrated the importance of lipids for development, sporulation and germination and their involvement in various physiological processes $(17,28,29,30,31)$.

Most fungi contain 5 to $32 \%$ lipids depending on culture conditions, developmental stage and species. The lipid content of spores of many fungi ranges from 5 to $17 \%$ dry weight, but spores of some species, such as rusts contain up to $35 \%$ lipid (19). The major factors influencing the extent of lipid production are the nature and proportion of carbon $(\mathrm{C})$ and nitrogen $(\mathrm{N})$ as nutrient sources in the medium (3). The major components of these lipids usually are triacylglycerides and glycerolphospholipids (phospholipids) that may be accompanied by sterols and their esters, fatty acids, sphingolipids, hydrocarbons etc. Fatty acids range from $\mathrm{C} 12$ to $\mathrm{C} 24$ in chain length. $\mathrm{C} 16$ palmitic acid usually is the majus saturated fatty acid, and oleic C18:1 and linoleic C18:2 are the major unsaturated fatty acids (19).

The objective of the present study was to assess the percentage of total lipids and the fatty acid composition of conidia and mycelia of a variety of $M$. anisopliae strains produced in two different culture media.

\section{MATERIAL AND METHODS}

Strains and culture media. The $M$. anisopliae strains used were obtained from the Germplasm Bank of the sector of Genetics of Microorganisms, Biology Institute, UNICAMP and originate from different hosts and geographic locations, as shown in Table 1. The strains were developed in the minimal medium (MM) and complete medium (CM) used for Aspergillus nidulans

\footnotetext{
* Corresponding author. Mailing address: Departamento de Genética e Evolução, Instituto de Biologia, Caixa Postal 6109, UNICAMP, CEP 13083-970, Campinas, SP, Brasil
} 
(16). The composition per liter: $\mathrm{MM}=6.0 \mathrm{~g} \mathrm{NaNO}_{3}, 0.52 \mathrm{~g}$ $\mathrm{KCl}, 0.52 \mathrm{~g} \mathrm{MgSO}_{4} .7 \mathrm{H}_{2} \mathrm{O}, 1.52 \mathrm{~g} \mathrm{KH}_{2} \mathrm{PO}_{4}$, trace amounts of $\mathrm{FeSO}_{4}$ and $\mathrm{ZnSO}_{4}$, and $10.0 \mathrm{~g}$ glucose; $\mathrm{CM}=$ add 2.0 g peptone, $0.5 \mathrm{~g}$ yeast extract, $1 \mathrm{ml}$ vitamin solution $(100.0 \mathrm{mg}$ nicotinic acid, $0.2 \mathrm{mg}$ p-aminobenzoic acid, $0.2 \mathrm{mg}$ biotin, $50.0 \mathrm{mg}$ pyridoxine, $100.0 \mathrm{mg}$ riboflavin and $50.0 \mathrm{mg}$ thiamin in $100 \mathrm{ml}$ of dionized water) and $1.5 \mathrm{~g}$ hydrolyzed casein to MM. The $\mathrm{pH}$ was adjusted to $\mathrm{pH} 6.8$ and solid medium was obtained by adding 15.0 g agar.

Production of mycelium and conidia for analysis of total lipids and fatty acid composition. The $M$. anisopliae strains were grown in liquid $\mathrm{CM}$ and $\mathrm{MM}$ with reciprocal shaking for 12 days at room temperature $\left(28^{\circ} \pm 1^{\circ} \mathrm{C}\right)$. The mycelium was retained by filtering the culture, through Whatman no. 1 filter paper in a Büchner funnel, washing with sterilized water to remove residual culture medium and then macerating in a mortar with liquid $\mathrm{N}_{2}$.

For the production of conidia, $M$. anisopliae strains were cultured on solid CM and MM on Petri dishes containing approximately $20 \mathrm{ml}$ culture medium and incubated at $28^{\circ} \mathrm{C}$ for 12 days. Dry mycelial and conidial mass was determined by maintaining samples at $70^{\circ} \mathrm{C}$ until dry matter reached a constant weight.

Lipid extraction and identification of fatty acids. Extraction was performed overnight with a Soxhlet extractor using a 2:1 mixture of chloroform/methanol $(\mathrm{v} / \mathrm{v})$. The solvents were then evaporated with gaseous $\mathrm{N}_{2}$ and the residue was considered to represent the total lipids.

Lipids obtained from mycelium and conidia were saponified with $0.5 \mathrm{~N} \mathrm{KOH} /$ methanol under reflux and esterified with $\mathrm{H}_{2} \mathrm{SO}_{4}-\mathrm{NH}_{4} \mathrm{Cl}$-methanol (6).
Fatty acids were identified by gas chromatography using a flame ion chromatography apparatus model CG 37-D with a 152-cm x 3.2-mm inner diameter glass column, with a support of Chromosorb WHP 100/200 mesh coated with $12 \%$ diethyleneglycol succinate (DEGS). The operating conditions were as follows: mobile phase maintained at $25 \mathrm{ml}$ per minute, column temperature $182^{\circ} \mathrm{C}$, detector temperature $290^{\circ} \mathrm{C}$, and vaporizer temperature $240^{\circ} \mathrm{C}$. Identification was based on retention time, and the relative percentages of fatty acids were determined by the area of the peaks in the chromatograms.

\section{RESULTS AND DISCUSSION}

Lipid contents in the mycelium and conidia of the 12 strains studied ranged from 12.13 to $49.27 \%$ dry weight. We used minimum medium (MM) and complete medium (CM) because they have a different $\mathrm{C} / \mathrm{N}$ ratio, with $\mathrm{MC}$ differing from $\mathrm{MM}$ by being enriched with peptone, yeast extract, vitamin solution and hydrolyzed casein. The use of these culture media has permitted biochemical and genetic studies on $M$. anisopliae $(13,1)$. Tables 2 and 3 show that the strains presented closely similar percentages of total lipid, and the Tukey test for averages of percent lipid content in mycelia cultured on MM and CM media showed a significant difference between means at the 5\% level of $\Delta=1.20$ for mycelia and of $\Delta=0.34$ for conidia, indicating variability within the strains for total lipid production, a variability that may increase when a larger number of strains is studied. Strains 5 and 7 of $M$. anisopliae var. majus did not present sizable differences from the strains of the variety anisopliae. Even though their conidial size was smaller than in the majus variety and the majus strains have been reported to

Table 1. Origin of Metarhizium anisopliae strains.

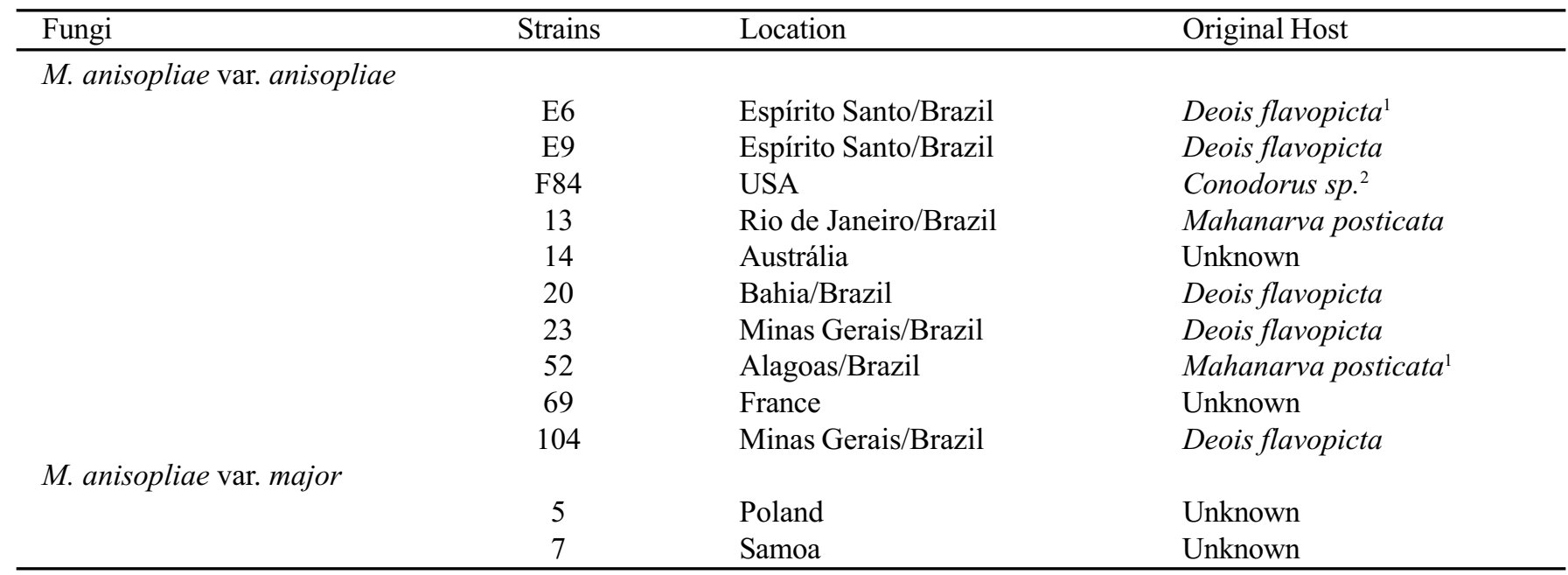

1- (Homoptera:Cercopidae)

2- (Coleoptera:Elateridae) 
be diploid (22), they did not show quantitative differences in total lipid content. When all the strains were considered as a whole in terms of lipid content in conidia cultured on MM or $\mathrm{MC}$, greater lipid accumulation was observed in conidia growing on MM, with analysis of variance showing a significant difference at the $5 \%$ level. Table 4 shows the significant differences greater or less than of CM versus MM for percentages of lipid content within mycelia and conidia using data shown on Table 2,3. These differences listed in Table 4 were submitted to $2 \times 2$ contingency analysis in order to determine the presence of association between lipid percentage in mycelia and conidia. The association between CM and MM for percent lipid content in mycelia and conidia, respectively, (Table 5) presented a chi square value with Yates correction $\left(\chi^{2}=0.1143\right)$ nonsignificant for 1 d.f., corresponding to $\mathrm{p}=0.740$ and confirmed by the exact Fischer test, $\mathrm{p}=0.727$, showing that there is independence for mycelia as well as for conidia when cultured on both $\mathrm{CM}$ and $\mathrm{MM}$ and the differences are due to the characteristics of the strains.

Table 6 shows the differences greater than and less than of mycelia and conidia for percentages of lipid content, within CM and MM, based on data shown on Table 2,3. These values were contrasted by $2 \times 2$ contingency analysis (Table 7) in order to determine the association between the results obtained on $\mathrm{CM}$ and MM media. The chi square value with Yates correction was not significant $\left(\chi^{2}=0.0429\right)$ for 1 d.f., corresponding to $p=0.844$, verified by the Fisher exact test $(\mathrm{p}=0.848)$, showing that there is no association between culture media, and like in Table 5 and 6 , the differences are related to the characteristics of the strains.

Table 2. Percentage of lipid content in mycelia of $M$. anisopliae strains cultured on complete and minimal media.

\begin{tabular}{cccccccc}
\hline \multicolumn{3}{c}{ Complete Medium (CM) } & & \multicolumn{3}{c}{ Minimal Medium (MM) } \\
\cline { 1 - 4 } $\begin{array}{c}\text { Array of } \\
\text { strain }\end{array}$ & $\begin{array}{c}\text { \% of } \\
\text { lipid }\end{array}$ & $\begin{array}{c}\text { Significant } \\
\text { Difference }\end{array}$ & $\begin{array}{c}\text { Array of } \\
\text { strain }\end{array}$ & $\begin{array}{c}\text { \% of } \\
\text { lipid }\end{array}$ & $\begin{array}{c}\text { Significant } \\
\text { Difference }\end{array}$ \\
\hline E6 & 49.27 & a & & F84 & 46.67 & a \\
E9 & 45.63 & b & & 5 & 46.03 & a \\
13 & 42.30 & c & & E6 & 43.70 & b \\
14 & 42.13 & c & & 69 & 37.80 & c \\
52 & 40.03 & d & & 23 & 34.20 & d \\
F84 & 37.23 & e & & E9 & 32.67 & e \\
5 & 36.20 & e & & 7 & 32.67 & e \\
69 & 36.20 & e & & 20 & 32.10 & e \\
23 & 32.13 & f & & 104 & 30.50 & f \\
7 & 30.17 & g & & 14 & 25.50 & g \\
104 & 28.80 & h & & 52 & 24.60 & g \\
20 & 27.76 & h & & 13 & 22.17 & h \\
\hline
\end{tabular}

Values are means of three replicates. Means with the same letter are not significantly different. The minimal significant difference between the means was $\Delta \%=1.20$
Table 3. Percentage of lipid content in conidia of $M$. anisopliae strains cultured on complete and minimal media.

\begin{tabular}{|c|c|c|c|c|c|}
\hline \multicolumn{3}{|c|}{ Complete Medium (CM) } & \multicolumn{3}{|c|}{ Minimal Medium (MM) } \\
\hline $\begin{array}{l}\text { Array of } \\
\text { strain }\end{array}$ & $\begin{array}{l}\% \text { of } \\
\text { lipid }\end{array}$ & $\begin{array}{l}\text { Significant } \\
\text { Difference }\end{array}$ & $\begin{array}{c}\text { Array of } \\
\text { strain }\end{array}$ & $\begin{array}{l}\% \text { of } \\
\text { lipid }\end{array}$ & $\begin{array}{l}\text { Significant } \\
\text { Difference }\end{array}$ \\
\hline 52 & 41.83 & $\mathrm{a}$ & E9 & 47.57 & $\mathrm{a}$ \\
\hline 5 & 36.13 & $\mathrm{~b}$ & 69 & 47.47 & $\mathrm{a}$ \\
\hline E9 & 36.10 & $\mathrm{~b}$ & E6 & 43.30 & $\mathrm{~b}$ \\
\hline 23 & 32.57 & $\mathrm{c}$ & 20 & 42.52 & $\mathrm{c}$ \\
\hline 7 & 32.33 & $\mathrm{c}$ & F84 & 40.20 & $\mathrm{~d}$ \\
\hline 20 & 30.70 & $\mathrm{~d}$ & 13 & 39.53 & $\mathrm{e}$ \\
\hline E6 & 30.67 & $\mathrm{~d}$ & 5 & 36.50 & $\mathrm{f}$ \\
\hline F84 & 30.63 & $\mathrm{~d}$ & 52 & 35.83 & $\mathrm{~g}$ \\
\hline 13 & 30.50 & $\mathrm{~d}$ & 104 & 35.37 & $\mathrm{~h}$ \\
\hline 69 & 28.67 & e & 7 & 34.73 & $\mathrm{i}$ \\
\hline 104 & 26.03 & $\mathrm{f}$ & 23 & 29.43 & $\mathrm{j}$ \\
\hline 14 & 19.17 & $\mathrm{~g}$ & 14 & 12.13 & $\mathrm{k}$ \\
\hline
\end{tabular}

Values are means of three replicates. Means with the same letter are not significantly different. The minimal significant difference between the means was $\Delta \%=0.34$

Table 4. Differences greater than $(>)$ and less than $(<)$ of $\mathrm{CM}$ versus MM within mycelia and conidia for percentages of lipid content, of M.anisopliae strains.

\begin{tabular}{cccccccc}
\hline \multirow{2}{*}{ Strain } & \multicolumn{3}{c}{ \% Lipid content in mycelia } & \multicolumn{3}{c}{ \% Lipid content in conidia } \\
\cline { 2 - 3 } & CM & CM vs MM & MM & & CM & CM vs MM & MM \\
\hline E6 & 49.27 & $>$ & 43.70 & & 30.67 & $<$ & 43.30 \\
E9 & 45.63 & $>$ & 32.67 & & 36.10 & $<$ & 47.57 \\
F84 & 37.23 & $<$ & 46.67 & 30.63 & $<$ & 40.20 \\
5 & 36.20 & $<$ & 46.05 & 36.13 & $<$ & 36.50 \\
7 & 30.17 & $<$ & 32.67 & 32.33 & $<$ & 34.73 \\
13 & 42.30 & $>$ & 22.17 & 30.50 & $<$ & 39.53 \\
14 & 42.13 & $>$ & 25.50 & 19.17 & $>$ & 12.13 \\
20 & 27.70 & $<$ & 32.10 & 30.70 & $<$ & 42.57 \\
23 & 32.13 & $<$ & 34.20 & 32.57 & $>$ & 29.43 \\
52 & 40.03 & $>$ & 24.60 & 41.83 & $>$ & 35.83 \\
69 & 36.20 & $<$ & 37.80 & 28.67 & $<$ & 47.47 \\
104 & 28.80 & $<$ & 30.50 & 26.03 & $<$ & 35.37 \\
\hline
\end{tabular}

Values are means of three replicates.

Table 5. Association between mycelia and conidia of M. anisopliae according to strains differences greater than and less than as in table 4 .

\begin{tabular}{|c|c|c|c|c|}
\hline $\begin{array}{l}\% \text { lipid in conidia } \\
\% \text { lipid in mycelia }\end{array}$ & $\mathrm{CM}>\mathrm{MM}$ & $\mathrm{CM}<\mathrm{MM}$ & Total & $\chi^{2}=0.1143_{\text {ns }}$ to \\
\hline $\mathrm{CM}>\mathrm{MM}$ & 2 & 3 & 5 & $\begin{array}{l}\text { Exact Fisher test } \\
\mathrm{p}=0.727_{\text {ns }}\end{array}$ \\
\hline $\mathrm{CM}<\mathrm{MM}$ & 1 & 6 & 7 & $\begin{array}{l}\text { ns - nonsignificant } \\
\text { at the of } 5 \%\end{array}$ \\
\hline Total & 3 & 9 & 12 & \\
\hline
\end{tabular}


Chesters and Peberdy (3) detected a correlation due to the $\mathrm{C} / \mathrm{N}$ ratio of the culture medium when they studied lipid production in Mortierella vinacea. There was also a variation not related to the culture medium in the occurrence of fatty acids both in quantitative and qualitative terms, with predominance of longchain $\mathrm{C} 16$ to $\mathrm{C} 18$ fatty acids.

According to percent of lipid in mycelia and conidia grown on $\mathrm{CM}$ and $\mathrm{MM}$, the strains (Table 1) can be assigned to 4 different groups: Group I , consisting of strains characterized by a higher lipid percentage in mycelium when grown on CM and a higher lipid percentage in conidia when grown on MM. This group comprises strains E6 and E9 isolated from Deois flavopicta (Homoptera: Cercopidae), the pasture spittlebug, and 13 from Mahanarva posticata (Homoptera: Cercopidae), the sugar-cane spittlebug. Group II comprises the strains with a higher lipid percentage in mycelium and conidia when grown on MM, i.e., strains F84, 5, 7, 20, 69 and 104 of different origins (Table 1). Group III comprises strains 14 and 52, which are

Table 6. Differences greater than $(>)$ and less than $(<)$ of mycelia $(\mathrm{M})$ and conidia (C) for percentages of lipid content within CM and MM media of M. anisopliae strains.

\begin{tabular}{ccccccccc}
\hline \multirow{2}{*}{ Strain } & \multicolumn{3}{c}{ Complete Medium (CM) } & & \multicolumn{3}{c}{ Minimal Medium (MM) } \\
\cline { 2 - 3 } & \%Lipid M & M vs C & \% Lipid C & & \%Lipid M & M vs C & \%Lipid C \\
\hline E6 & 49.27 & $>$ & 30.67 & & 43.70 & $>$ & 43.30 \\
E9 & 45.63 & $>$ & 36.10 & & 32.67 & $<$ & 47.57 \\
F84 & 37.23 & $>$ & 30.63 & & 46.67 & $>$ & 40.20 \\
5 & 36.20 & $>$ & 36.13 & & 46.05 & $>$ & 36.50 \\
7 & 30.17 & $<$ & 32.33 & & 32.67 & $<$ & 34.73 \\
13 & 42.30 & $>$ & 30.50 & & 22.17 & $<$ & 39.53 \\
14 & 42.13 & $>$ & 19.17 & & 25.50 & $>$ & 12.13 \\
20 & 27.76 & $<$ & 30.70 & & 32.10 & $<$ & 42.52 \\
23 & 32.13 & $<$ & 32.57 & & 34.20 & $>$ & 29.43 \\
52 & 40.03 & $<$ & 41.83 & & 24.60 & $<$ & 35.83 \\
69 & 36.20 & $>$ & 28.67 & & 37.80 & $<$ & 47.47 \\
104 & 28.80 & $>$ & 26.03 & & 30.50 & $<$ & 35.37 \\
\hline
\end{tabular}

Values are means of three replicates.

Table 7. Association between $\mathrm{CM}$ and $\mathrm{MM}$ according to differences greater than and less than as in table 6 for conidia $(\mathrm{C})$ and mycelia $(\mathrm{M})$ of $M$. anisopliae strains.

\begin{tabular}{|c|c|c|c|c|}
\hline $\mathrm{MM}$ & $M>$ & $\mathrm{M}<$ & Total & \multirow{4}{*}{$\begin{array}{l}\chi^{2}=0.0429_{\text {ns }} \text { to } \\
1 \text { d.f.p }=0.844 \\
\text { Exact Fisher test } \\
p=0.848_{\text {ns }} \\
\text { ns }- \text { nonsignificant at the } \\
\text { of } 5 \%\end{array}$} \\
\hline CM & & & & \\
\hline $\mathrm{M}>\mathrm{C}$ & 4 & 4 & & \\
\hline $\mathrm{M}<\mathrm{C}$ & 1 & 3 & 4 & \\
\hline Total & 5 & 7 & 12 & \\
\hline
\end{tabular}

characterized by a higher lipid percentage both in mycelium and conidia when grown on CM. Group IV consists of strain 23 , with a higher lipid percentage in mycelium grown on MM and a higher lipid percentage in conidia grown on CM.

In fungi in general, lipids have been reported to be important for germination, in addition to having other functions $(4,15,23)$. Uredospores of rust fungi have little if any exogenous nutritional requirements for germination, since they germinate quite readily in the presence of only distilled water; thus, a high lipid content is the principal source of energy for spore germination (7). Smith and Silverman (20) reported a 30 to $40 \%$ decrease in lipids during the early phase of germination. In a study on Rhizopus stolonifer, (30) was observed that spore having a low concentration of lipid required a new synthesis of lipid during the early stages of spore germination compared to spores with a high concentration of lipid. The importance of lipids has also been reported with respect to the need for water at the time of germination for different classes of fungi. McKeen(11) observed in Eysiphe graminis sp. Hordey that large quantities of lipid are oxidized in the process of respiration and the oxidation of large amounts of hydrogen in the molecule results in the production of a corresponding large amount of water. Many powdery mildew investigators have found that mildew conidia may germinate on dry glass slides in air at zero or extremely low relative humidity $(2,8,32)$. The study of lipids may make an important contribution in view of the importance of conidial germination under conditions of low relative humidity. Few investigations of this type are available for entomopathogenic fungi.

For large-scale utilization, $M$. anisopliae conidia are produced on rice medium ( $100 \mathrm{~g}$ white rice and $70 \mathrm{ml}$ of distilled water, autoclaved at $1 \mathrm{~atm}$ for 20 minutes) which contains a high $\mathrm{C} / \mathrm{N}$ ratio. This medium seems to favor a higher lipid concentration in conidia, related to the caracteristic of the strain as is the case for MM. As shown by ANOVA, the F value was 5.90 (significant at the $1 \%$ level) for culture media as a whole, measured by the medium versus strain interaction for 1 and 11 d.f., a fact that explains a higher frequency of values in $\mathrm{CM}<$ MM.The lipid concentration in conidia as well as the fatty acid quality could be important factors allowing the fungus better environmental expression under low relative humidity.

According to Soper and Ward (21), seasonal epizootics of Zoophthora radicans (Bref). Batko (= Entomophthora sphaerosperma Fresenius) on the spotted alfalfa aphid, Therioaphis maculata (Buckton), in Bet Shan Valley, Israel, provide an excellent example. This valley is hot and dry, not a place one would logically look for insect fungi if moisture were limiting. Similar reports of epizootics were made for Entomophaga grylli (Fres.) Batko (= Entomophthora grylli Fres.) on grasshoppers in Alice Springs (Gibson Desert of Australia), a fact that may be related to the physiological quality of conidia in terms of lipid and fatty acid composition.

There was no variability in terms of fatty acids. Palmitic 
C16:0 acid, stearic C18:0 acid, oleic C18:1 acid and linoleic C18:2 acid were the most abundant fatty acids both in conidia and mycelia in the two media used. Also, there were smaller quantities of $\mathrm{C} 16: 2, \mathrm{C} 18: 3$ and of trace amounts of C 14:1, C16:2 and $\mathrm{C} 16: 3$ (Tables 8 and 9).

The values of the above percentages, minus those of fatty

Table 8. Fatty acid composition of the mycelium of $M$. anisopliae strains cultured in complete medium $(\mathrm{CM})$ and minimal medium (MM).

\begin{tabular}{|c|c|c|c|c|c|c|c|c|c|c|c|c|c|c|c|c|c|c|c|c|c|c|}
\hline \multirow{3}{*}{ Strain } & \multicolumn{22}{|c|}{ Relative fatty acid percentage } \\
\hline & \multicolumn{2}{|c|}{$\mathrm{C} 14: 1^{\mathrm{a}}$} & \multicolumn{2}{|c|}{ C16:0 } & \multicolumn{2}{|c|}{ C16:1 } & \multicolumn{2}{|c|}{ C16:2 } & \multicolumn{2}{|c|}{ C16:3 } & \multicolumn{2}{|c|}{ C18:0 } & \multicolumn{2}{|c|}{ C18:1 } & \multicolumn{2}{|c|}{ C18:2 } & \multicolumn{2}{|c|}{$\mathrm{C} 18: 3$} & \multicolumn{2}{|c|}{$>\mathrm{C} 18$} & \multicolumn{2}{|c|}{ G.I. $^{b}$} \\
\hline & $\mathrm{CM}$ & MM & $\mathrm{CM}$ & $\mathrm{MM}$ & $\mathrm{CM}$ & MM & $\mathrm{CM}$ & $\mathrm{MM}$ & $\mathrm{CM}$ & $\mathrm{MM}$ & $\mathrm{CM}$ & $\mathrm{MM}$ & $\mathrm{CM}$ & $\mathrm{MM}$ & $\mathrm{CM}$ & MM & $\mathrm{CM}$ & MM & $\mathrm{CM}$ & $\mathrm{MM}$ & $\mathrm{CM}$ & MM \\
\hline E6 & & + & 23.9 & 26.1 & & & + & 1.4 & + & + & 2.6 & 0.7 & 17.4 & 16.7 & 55.6 & 55.1 & & + & & & 1.3 & 1.3 \\
\hline E9 & & + & 21.0 & 30.3 & & & + & + & & & 2.6 & 2.7 & 20.5 & 16.3 & 55.9 & 50.7 & & & & & 1.3 & 1.2 \\
\hline F84 & & + & 22.8 & 17.8 & & & & + & & + & 3.8 & 1.7 & 21.7 & 16.8 & 51.7 & 63.7 & & & & & 1.2 & 1.4 \\
\hline $5^{*}$ & & & 30.3 & 29.9 & & & 1.2 & 2.3 & & & 11.9 & 5.9 & 23.5 & 18.7 & 33.1 & 39.5 & & 2.2 & & 1.5 & 0.9 & 1.1 \\
\hline $7^{*}$ & & & 23.7 & 23.5 & & & & + & & & 6.8 & 9.5 & 24.8 & 24.3 & 44.7 & 42.7 & & + & & + & 1.1 & 1.1 \\
\hline 13 & & & 25.3 & 29.4 & & & + & + & + & + & 3.7 & 2.4 & 29.8 & 12.1 & 41.2 & 56.1 & & & & & 1.1 & 1.2 \\
\hline 14 & + & & 21.1 & 27.7 & + & & 1.5 & & + & + & 1.5 & 8.3 & 17.7 & 43.5 & 58.2 & 20.5 & & + & + & & 1.4 & 0.9 \\
\hline 20 & & & 23.0 & 27.2 & & + & + & & & & 10.1 & 8.6 & 26.5 & 33.8 & 40.4 & 30.4 & + & + & + & + & 1.1 & 1.0 \\
\hline 23 & & & 20.4 & 28.3 & & & + & & & & 1.9 & 6.7 & 22.9 & 30.9 & 54.8 & 34.1 & & + & + & & 1.3 & 1.0 \\
\hline 52 & & & 27.6 & 23.1 & & & & + & & & 5.2 & 7.6 & 17.4 & 22.4 & 49.7 & 46.9 & & & + & & 1.1 & 1.2 \\
\hline 69 & & 1.0 & 24.6 & 25.3 & & & & & + & + & 6.4 & 4.1 & 20.8 & 14.8 & 48.2 & 54.8 & + & & & & 1.2 & 1.2 \\
\hline 104 & + & & 26.8 & 23.2 & + & & + & + & + & + & 4.4 & 7.6 & 32.9 & 22.2 & 35.9 & 47.6 & + & & & & 1.0 & 1.2 \\
\hline
\end{tabular}

a: Fatty acids are designated as number of carbon atoms: number of double bonds.

b: E.U., extent of unsaturation reported as number of double bonds $/ \mathrm{mol}$ fatty acid.

E.U. $=[1.0 \times(\%$ monoene $)+2.0 \times(\%$ diene $)+3.0 \times(\%$ triene $)]: 100$

+ : indicates trace amounts.

*: majus strains.

Table 9. Fatty acid composition of the conidia of $M$. anisopliae strains cultured in complete medium (CM) and minimal medium (MM).

\begin{tabular}{|c|c|c|c|c|c|c|c|c|c|c|c|c|c|c|c|c|c|c|c|c|c|c|}
\hline \multirow{3}{*}{ Strain } & \multicolumn{22}{|c|}{ Relative fatty acid percentage } \\
\hline & \multicolumn{2}{|c|}{$\mathrm{C} 14: 1^{\mathrm{a}}$} & \multicolumn{2}{|c|}{ C16:0 } & \multicolumn{2}{|c|}{ C16:1 } & \multicolumn{2}{|c|}{ C16:2 } & \multicolumn{2}{|c|}{ C16:3 } & \multicolumn{2}{|c|}{ C18:0 } & \multicolumn{2}{|c|}{ C18:1 } & \multicolumn{2}{|c|}{ C18:2 } & \multicolumn{2}{|c|}{ C18:3 } & \multicolumn{2}{|c|}{$>\mathrm{C} 18$} & \multicolumn{2}{|c|}{ G.I. $^{b}$} \\
\hline & $\mathrm{CM}$ & MM & $\mathrm{CM}$ & MM & $\mathrm{CM}$ & MM & $\mathrm{CM}$ & MM & $\mathrm{CM}$ & $\mathrm{MM}$ & CM & MM & $\mathrm{CM}$ & $\mathrm{MM}$ & $\mathrm{CM}$ & MM & $\mathrm{CM}$ & MM & $\mathrm{CM}$ & MM & $\mathrm{CM}$ & MM \\
\hline E6 & + & & 36.3 & 26.8 & & & 1.1 & & + & + & 2.7 & 4.1 & 23.1 & 28.6 & 36.8 & 40.5 & + & + & & & 1.0 & 1.1 \\
\hline E9 & + & & 29.9 & 25.6 & & & + & + & + & + & 1.9 & 1.7 & 21.6 & 28.2 & 46.6 & 44.5 & & + & & & 1.1 & 1.2 \\
\hline F84 & + & & 25.6 & 19.5 & & & 1.7 & & + & & 5.6 & 4.0 & 43.5 & 40.1 & 23.6 & 36.4 & + & & & & 0.9 & 1.1 \\
\hline $5^{*}$ & + & & 22.5 & 25.0 & & & 1.6 & + & + & + & 3.2 & 8.1 & 29.2 & 42.0 & 40.2 & 24.9 & 3.3 & + & & & 1.2 & 0.9 \\
\hline $7^{*}$ & & & 21.2 & 24.6 & & & + & + & & & 7.5 & 5.2 & 41.3 & 48.5 & 30.0 & 21.7 & & + & & & 1.0 & 0.9 \\
\hline 13 & + & & 22.9 & 25.9 & + & & 1.3 & 1.6 & + & & 2.0 & 1.2 & 20.6 & 29.6 & 52.0 & 41.7 & 1.2 & + & & + & 1.3 & 1.2 \\
\hline 14 & + & + & 21.4 & 25.3 & & + & + & + & + & + & 5.3 & 7.2 & 38.9 & 44.7 & 34.4 & 22.8 & + & + & & & 1.1 & 0.9 \\
\hline 20 & & & 26.1 & 25.8 & & & + & + & & & 2.3 & 3.2 & 26.6 & 27.2 & 43.6 & 35.9 & 1.4 & 2.5 & & 5.4 & 1.1 & 1.1 \\
\hline 23 & & & 22.3 & 31.4 & & & + & + & + & + & 6.1 & 4.9 & 42.8 & 31.6 & 28.9 & 32.1 & + & + & & & 1.0 & 1.0 \\
\hline 52 & & & 16.7 & 15.9 & & & + & 1.1 & & & 2.8 & 2.4 & 29.8 & 31.5 & 49.6 & 49.1 & 1.1 & & & & 1.3 & 1.3 \\
\hline 69 & & & 29.8 & 21.4 & & & 1.2 & 1.5 & & + & 4.0 & 3.6 & 37.6 & 44.0 & 27.4 & 29.5 & + & + & & & 1.0 & 1.1 \\
\hline 104 & + & & 25.5 & 20.3 & & & 2.1 & + & + & & 2.6 & 4.9 & 31.5 & 41.6 & 37.2 & 33.2 & + & + & 1.1 & & 1.1 & 1.1 \\
\hline
\end{tabular}

a: Fatty acids are designated as number of carbon atoms: number of double bonds.

b: E.U., extent of unsaturation reported as number of double bonds $/ \mathrm{mol}$ fatty acid.

E.U. $=[1.0 \times(\%$ monoene $)+2.0 \times(\%$ diene $)+3.0 \times(\%$ triene $)]: 100$

$+:$ indicates trace amounts.

*: majus strains. 
acids C14:1, C16:1 C16:2 and C16:3, and those of the $>\mathrm{C} 18$ carbon chain, of which traces or small percentages occur, were analyzed by the Friedman test to determine the rank contrasts (RC) corresponding to each fatty acid for the strains as a whole (Table 10). The table shows the presence of significant differences between RC16:0 and RC18:0 which were practically identical for $\mathrm{CM}$ and $\mathrm{MM}$ in mycelium, whereas the conidia presented significant differences in $\mathrm{CM}$ and nonsignificant differences in MM.

The RC16:0-RC18:1 contrasts were not significantly

Table 10. Chi square $\left(\chi^{2}\right)$ and differences obtained by the Friedman test between the rank values corresponding to the mean percentages of fatty acids $\mathrm{C} 16: 0, \mathrm{C} 18: 0, \mathrm{C} 18: 1$ and $\mathrm{C} 18: 2$ in Tables 8 and 9, present in mycelium (M) and conidia (C) of $M$. anisopliae, cultured in complete medium (CM) and in minimal medium (MM). $\left(\mathrm{dms}_{5 \%}=16.2\right.$ and $\left.\mathrm{dms}_{10 \%}=19.7\right)$.

\begin{tabular}{lccccc}
\hline Rank contrasts (RC) & \multicolumn{2}{c}{ Mycelium (M) } & & \multicolumn{2}{c}{ Conidia (C) } \\
\cline { 6 - 7 } \cline { 5 - 6 } between fatty acids & CM & MM & & CM & MM \\
\hline |RC16:0 - RC18:0 & $19^{*}$ & $20^{* *}$ & & $16^{?}$ & $14^{\mathrm{NS}}$ \\
$|\mathrm{RC} 16: 0-\mathrm{RC} 18: 1|$ & $2^{\mathrm{NS}}$ & $4^{\mathrm{NS}}$ & & $10^{\mathrm{NS}}$ & $16 ?$ \\
$|\mathrm{RC} 16: 0-\mathrm{RC} 18: 2|$ & $17^{*}$ & $16^{?}$ & & $14^{\mathrm{NS}}$ & $14^{\mathrm{NS}}$ \\
$|\mathrm{RC} 18: 0-\mathrm{RC} 18: 1|$ & $17^{*}$ & $16^{?}$ & & $26^{* *}$ & $30^{* *}$ \\
$|\mathrm{RC} 18: 0-\mathrm{RC} 18: 2|$ & $36^{* *}$ & $36^{* *}$ & & $30^{* *}$ & $28^{* *}$ \\
$|\mathrm{RC} 18: 1-\mathrm{RC} 18: 2|$ & $19^{*}$ & $20^{* *}$ & & $4^{\mathrm{NS}}$ & $2^{\mathrm{NS}}$ \\
\hline$\chi_{\mathrm{r}}^{2}$ & $32.5^{* * *}$ & $32.8^{* * *}$ & $26.8^{* * *}$ & $29.8^{* * *}$ \\
\hline
\end{tabular}

NS: Nonsignificant difference at the $5 \%(\mathrm{p}>0.05)$

?: Tendency to a significant difference close to the $5 \%$ level.

*: Significant difference at the $5 \%$ level $(0.02<\mathrm{p}<0.05)$

**: Highly significant difference at the $1 \%$ level $(0.001<\mathrm{p}<0.01)$

$* * *$ : Highly significant difference at the $0.1 \%$ level $(\mathrm{p}<0.001)$

$\mathrm{dms}=$ minimal/significant difference different, except for a tendency observed for conidia in MM, indicating that the two fatty acids appear to be quantitatively identical. A significant difference for mycelium in $\mathrm{CM}$ and a significant tendency for MM was observed for RC18:0 and RC18:1, together with a highly significant tendency for conidia in $\mathrm{CM}$ and MM. Practically the same results were observed for RC18:0-RC18:2 contrasts. The contrasts for RC18:1 and RC18:2 showed significant differences only for mycelium in $\mathrm{CM}$ and highly significant differences in MM.

On the basis of the data concerning fatty acid percentages (Tables 8 and 9) normalized by angular transformation, $\alpha^{0}=\operatorname{arc}$ $\sin \sqrt{p}$, where $p=(\% / 100)$, we performed analysis of variance for each fatty acid (C16:0, C18:0, C18:1 and C18:2) in order to determine the variances of the strains, culture media, mycelia and conidia and their respective interactions (Table 11). No significant interactions were observed for any fatty acid and no significant $\mathrm{F}$ values were obtained for any treatment, except for the mycelium and conidium treatment for fatty acids $\mathrm{C} 18: 1$ and $\mathrm{C} 18: 2$, whose respective values, $\mathrm{F}=40.187$ and $\mathrm{F}=21.985$, were highly significant for 1 and 11 d.f. Table 11 also shows that the mean square of the error, coefficient of variation $(\mathrm{CV})$ and Cochran coefficient of homogeneity confirm good variability and homogeneity between the variances of the different fatty acids.

In view of the significant values obtained, we tested the differences between the means $\left(\alpha^{\circ}\right)$ for mycelia and conidia in $\mathrm{CM}$ and $\mathrm{MM}$ and in the two media together for the two fatty acids C18:1 and C18:2 (Table 12). The differences between mycelia and conidia were all highly significant, with the highest means being obtained for conidia for fatty acid C18:1 and the highest means being obtained for mycelia for fatty acid C18:2 . This suggests that the presence of each fatty acid must be

Table 11. F values obtained in the ANOVAS applied to the percentages of fatty acids C16:0, C18:0, C18:1 and C18:2, presents in M. anisopliae mycelium (M) and conidia (C) grown in complete medium and minimal medium (Tables 8 and 9) normalized by the formula $\alpha^{\circ}=\operatorname{arc} \cdot \sin \sqrt{p}$ and their corresponding s2, coefficient of variation (CV), and Cochran homogeneity test (C).

\begin{tabular}{lccccc}
\hline & \multicolumn{5}{c}{ Fatty acids } \\
\cline { 2 - 6 } Sources of variation & GL & C16:0 & C18:0 & C18:1 & C18:2 \\
\hline Strains (S) & 11 & $2.263 \mathrm{NS}$ & $2.592 \mathrm{NS}$ & $2.600 \mathrm{NS}$ & $2.506 \mathrm{NS}$ \\
Culture media (CM) & 1 & $0.003 \mathrm{NS}$ & $0.319 \mathrm{NS}$ & $1.493 \mathrm{NS}$ & $1.058 \mathrm{NS}$ \\
(M and C) & 1 & $2.817 \mathrm{NS}$ & $2.874 \mathrm{NS}$ & $40.187^{* * *}$ & $21.985^{* * *}$ \\
$\mathrm{~S} \times \mathrm{CM}$ & 11 & $1.164 \mathrm{NS}$ & $1.769 \mathrm{NS}$ & $0.517 \mathrm{NS}$ & $1.811 \mathrm{NS}$ \\
$\mathrm{S}$ x M and C & 11 & $1.929 \mathrm{NS}$ & $0.116 \mathrm{NS}$ & $1.159 \mathrm{NS}$ & $2.211 \mathrm{NS}$ \\
$\mathrm{CM}$ x M and C & 1 & $3.891 \mathrm{NS}$ & $0.001 \mathrm{NS}$ & $0.855 \mathrm{NS}$ & $0.002 \mathrm{NS}$ \\
\hline S x CM x M and C (error) & 11 & $\mathrm{~s} 2=4.27825$ & $\mathrm{~s} 2=8.77197$ & $\mathrm{~s} 2=18.28556$ & $\mathrm{~s} 2=17.73419$ \\
\hline \multicolumn{1}{c}{ TOTAL } & 47 & $\mathrm{CV}=7.02 \%$ & $\mathrm{CV}=24.72 \%$ & $\mathrm{CV}=13.44 \%$ & $\mathrm{CV}=10.54 \%$ \\
\cline { 2 - 6 } & $\mathrm{C}=0.381 \mathrm{NS}$ & $\mathrm{C}=0.364 \mathrm{NS}$ & $\mathrm{C}=0.386 \mathrm{NS}$ & $\mathrm{C}=0.407 \mathrm{NS}$ & \\
\hline
\end{tabular}

Rejection limit $\alpha=0.05$ : NS p $>0.05, * 0.01<\mathrm{p}<0.05, * * 0.001<\mathrm{P}<0.01, * * * \mathrm{p}<0.001$

CV precision: optimum up to $10 \%$, good up to $20 \%$, acceptable up to $30 \%$, imprecise above $30 \%$

Cochran homogeneity test, rejection limit $\alpha=0.05, \mathrm{C}=0.477$ 
Table 12. Test between means $\left(\alpha^{\circ}\right)$ mycelia $(\mathrm{M})$ and conidia $(\mathrm{C})$ in $\mathrm{CM}$ and $\mathrm{MM}$ media, and total of $M$. anisopliae strains for $\mathrm{C} 18: 1$ and $\mathrm{C} 18: 2$ given as significant in Table 11.

\begin{tabular}{|c|c|c|c|c|c|c|}
\hline \multirow{2}{*}{ Fatty acid } & \multirow{2}{*}{$\begin{array}{l}\text { Culture } \\
\text { media }\end{array}$} & \multicolumn{2}{|c|}{ Mycelia (M) } & \multicolumn{2}{|c|}{ Conidia (C) } & \multirow{2}{*}{$\begin{array}{c}\text { Values of } \mathrm{t} \text { for } 11 \mathrm{GL} \\
\text { of } \alpha^{\circ} \mathrm{M}-\alpha^{\circ} \mathrm{C}\end{array}$} \\
\hline & & $\alpha^{\circ}$ & $\%$ corr. ${ }^{*}$ & $\alpha^{\circ}$ & $\%$ corr. & \\
\hline \multirow{3}{*}{ C18:1 } & $\mathrm{CM}$ & 27.72000 & 21.6 & 34. 40333 & 31.6 & $3.828 * *$ \\
\hline & $\mathrm{MM}$ & 28. 09167 & 22.2 & 37.05833 & 36.3 & $5.136 * * *$ \\
\hline & As a whole & 27.90833 & 21.9 & 35.73333 & 24.1 & $6.499 * * *$ \\
\hline \multirow{3}{*}{ C18:2 } & $\mathrm{CM}$ & 43.51667 & 47.4 & 37.65000 & 37.6 & $3.412 * *$ \\
\hline & MM & 42. 10000 & 44.9 & 36. 56667 & 35.5 & $3.219 * *$ \\
\hline & As a whole & 42.08333 & 46.2 & 37. 10833 & 36.4 & $4.689 * * *$ \\
\hline
\end{tabular}

$* \%$ corr. $=\%$ corrected from $\alpha^{\mathrm{o}}\left(\%=\operatorname{sen}^{2} \alpha .100\right)$

important for the development of each structure, since the C18:1 content was slightly higher in conidia, whereas the $\mathrm{C} 18: 2$ content was much higher in mycelia.

The most abundant fatty acids in mycelia and conidia were, in decreasing order: linoleic acid (C18:2), palmitic acid (C16:0), oleic acid (C18:1) and stearic acid (C18:0) (Tables 8 and 9). Strains E6, E9, F84, 14, 23, 52 and 69 showed above average production of linoleic acid and, coincidentally, strains E6, E9 and 52 are those most extensively employed in pest control in Brazil, E6 and E9 for pasture spittlebug and 52 for sugar cane spittlebug, enforcing the importance of such studies on lipid and fatty acids related to the environmental expression of the fungus.No variation in the quality of fatty acids has been observed in mycelia of other fungi developed in different culture media (9). The same occurs for M. anisopliae, demonstrating the constitutive ability of this fungus to produce these fatty acids and its heteromorphism for this activity, since minimal medium contains only carbon and inorganic nitrogen sources and mineral salts. The fatty acids detected for M. anisopliae strains in the present study support the data of Shan (19), who divided fungi into two groups according to their capacity for synthesis of alphalinoleic acid, with Ascomycetes, Basidiomycetes and Deuteromycetes being classified as synthetizers.

Although the same fatty acids were detected in mycelia and conidia, they were present in different quantities, with a larger amount of alpha-linoleic acid occurring in mycelium.

The extent of unsaturation was 0.9 to 1.4 , slightly lower than observed in mesophilic fungi, whose values are 0.96 to 1.60 . Also, mesophilic fungi (minimum temperature above $0^{\circ} \mathrm{C}$, maximum below $50^{\circ} \mathrm{C}$ and optimum between 15 and $40^{\circ} \mathrm{C}$ ) have larger quantities of linoleic acid (14), where $M$. anisopliae must be included, whereas thermophilic fungi (minimum temperature at or above $20^{\circ} \mathrm{C}$, maximum at or above $50^{\circ} \mathrm{C}$ and optimum somewhere in the higher half of that range) have more oleic acid (12). The extent of unsaturation is a little higher in the mycelial form than in the conidial form due to linoleic acid and oleic acid. Linoleic acid has also been detected in larger amounts in Penicillium atrovenetum, where it represents $66 \%$ of all fatty acids (28). During the germination of $P$. atrovenetum spores, linoleic acid decreased, whereas oleic acid incresead (28). Linoleic acid strongly helps the oxidative processes of the cell by acting as a hydrogen acceptor, as reported for Penicillium chrysogenum (5)

The study of fatty acid composition has been used for the identification of species of entomopathogenic fungi $(10,24,25$, $26,27)$. However, studies on lipid and fatty acids at the physiological and genetic level may permit the selection of strains for environmental persistance and expression at the epizootic level and may provide information for their large-scale production and utilization.

\section{ACKNOWLEDGMENTS}

The authors thank Mr. Anthony Grefig (Boyce Thompson Institute at Cornell University- Ithaca, NY.USA) and Dr. João Paulo Feijão Teixeira (Instituto Agronomico de Campinas-IACCampinas-SP. Brasil) for their kind assistance in several ways, and also for technical assistance, and Fundação de Amparo a Pesquisa do Estado de São Paulo-Brasil, Conselho Nacional de Desenvolvimento Cientifico e Tecnológico-DF, Brasil and FINEP/PADCT-Rio de Janeiro, RJ, Brasil for financial support.

\section{RESUMO}

\section{Lipídios totais e ácidos graxos em linhagens de Metarhizium anisopliae}

Dois estágios de desenvolvimento a saber: conídio (C) e micélio (M) em 10 linhagens de Metarhizium anisopliae var. anisopliae e $2 \mathrm{M}$. anisopliae var. majus, foram estudados em dois diferentes meios de cultivos, minimo (MM) e completo (MC). As linhagens apresentaram-se similares quanto a porcentagem de lipídios totais, porém submetidas ao teste de Tukey, as médias dos conteúdos de lipídios do conídio (C) e do 
micélio (M) cultivados em meio MM e CM respectivamente, mostraram diferença significativa ao nível de $5 \%$, indicando assim variabilidade para a produção de lipídios totais. As linhagens 5 e 7, ambas da var. majus, não apresentam diferenças mensuráveis da variedade anisopliae. Com os ácidos graxos C18:1 e C18:2 oléico e linoléico respectivamente, as diferenças foram todas altamente significativas $(\mathrm{p}=1 \%)$ com a mais alta média de C18:1 para conídio e C18:2 para micélio.

Palavras-chave: lipídios, ácidos graxos, Metarhizium anisopliae, fungo entomopatogênico, controle microbiano

\section{REFERENCES}

1. Bagagli, E.; Valadares, CM.C.C.; Azevedo,J.L.. Parameiosis in the entomopathogenic fungus Metarhizium anisopliae. Revista Brasileira de Genética, 14: 261-271, 1991

2. Brodie, H. J. Further observations on the mechanism of germination of the conidia of various species of powdery mildew at low humidity. Can. J. Res.,23: 198-211, 1945.

3. Chesters, C.G.C. ; Peberdy, J.F. Nutritional factors in relation to growth and fat synthesis in Mortierella vinacea. J. Gen. Microbiol. , 41: $127-$ 134, 1965.

4. Cochrane, V.W.; Cochrane, J. C.; Collins,C.B.; Serafin,F.G. Spores germination and metabolism in Fusarium solani. Amer.J. Bot., 50: 806$814,1963$.

5. Gaby, W.L.; Hadley, C.; Kaminski, Z.C. A study of lipides of Penicillium chrysogenum. J. of Biol. Chem. , 227: 853 - 861, 1957.

6. Hartman, L. ; Largo, R.C.A. Rapid preparation of fatty acid methyl esteres from lipids. Lab. Prac., London, 20: 475 - 476, 1973.

7. Jackson, L.L.; Frear, D.S. Lipids of rust fungi. I. Lipid metabolism of germinating flax rust uredospores. Can. J. Biochem., 45: 1309-1315, 1967.

8. Jhooty,J.S.; Mckeen,W.E. Water relations of asexual spores of Sphaerotheca macularis (Wallr.Ex Fr.) Cooke and Erysiphe polygoni DC. Can. J. Microbiol., 11:531-538., 1965.

9. Johnk, J.S. ; Jones, R.K. Differentiation of population AG-2-2 of Rizoctonic solani by analysis of cellular fatty acids. Phytopathology, 83: $278-283$, 1994.

10. Latgé, J. P. ; Bièvre, C. Lipid composition of Entomophthora obscura. Hall \& Dunn. J. of General Microbiol. ,121: 151 - 158, 1980.

11. McKeen, W.E. 1970. Lipid in Erysiphe graminis hordei and its possible role during germination. Canadian Journal of Microbiol., 16:10411044,1970 .

12. Messias, C.L. Fungos, sua importância para o controle de insetos de importância médica e agrícola. Mem. Inst. Oswaldo Cruz, 84. Supl. II. $57-59,1989$.

13. Messias, C.L. ; Azevedo, J.L. Parasexuality in the Deuteromycete Metarhizium anisopliae. Transactions of the Bristish Mycological Society, 75: 473-477, 1986.
14. Mumma, R.O.; Fergus, C.L.; Sekura, R.D.The lipids of thermophilic fungi: lipid composition comparisons between thermophilic and mesophilic fungi. Lipids, 5: 100 - 103, 1970.

15. Owens, R.G. Metabolism of fungus spores. I. Oxidation and accumulation of organic acids by conidia of Neurospora sitophila. Contri. Boyce Thompson Inst. ,18, 125-144, 1955.

16. Pontecorvo, G.; Roper, J.A.; Hemmons, L.M.; McDonald, K.F.; Bufton, A.W.J. The genetics of Aspergillus nidulans. Adv. Genet., 5, 141-148, 1953.

17. Rattray, J.B.M. Lipids of yeast. Bacteriol. Rev ., 39: 197-231, 1975.

18. Roberts, D.W.; Fuxa, I.R.; Gaugler, R.; Goettel, M.; Jaques, R.; Maddox, J. Use of pathogens in insect control. In: Handbook of Pest Management in Agriculture, Pimentel, D. (Ed.) CRC Press. Boca Raton. FL. USA, 1991, p.243-278.

19. Shan, R. The polyunsatured fatty acids of microrganisms. Adv. in Lipid Res., 4: 107-174, 1966.

20. Smith, J.D.; Silverman, P.M. Lipid turnover during morphogenesis in the water mold Blastocladiella emersonii. Biochim. Biophys. Acta., 54: 11911197, 1973.

21. Soper, R. S. ; Ward, M. G. Production, Formulation and Application of Fungi for Insect Control. In: Biological Control in Crop Production. Beltsville V Symposia in Agricultural Resarch.ed. Papavizas, G .C. (ed.) Allanheld, Osmun, \& Co.Publishers,Inc.Totowa,NJ. USA. 1981,p. 161180.

22. St. Leger, R.J.; May, B.; Allee, L.L.; Frank, D.C.; Staples, R.C.; Roberts, D.W. Genetic differences in allozymes and in formation of infection structures among isolates of the entomopathogenic fungus Metarhizium anisopliae. J. Invertebr. Pathol. 60: 89 - 101, 1992.

23. Turian, G. and Bianchi,D.E. Conidiation in Neurospora .Bot. Ver. 38 , $119-154,1972$

24. Tyrrell, D. ; Weatherston, J. The fatty acid composition of some Entomophthoraceae. IV. The occurrence of branched-chain fatty acids in Conidiobulus species. Can. J. Microbiol., 22: 1058 - 1060, 1976.

25. Tyrrell, D. The fatty acid compositions of 17 Entomophtora isolates. Can. J. Microbiol., 13: 755 - 760, 1967.

26. Tyrrell, D. The fatty acid composition of some Entomophthoraceae. II. The occurrence of branched-chain fatty acids in Conidiobulus denaesporus Drechsl. Lipids, 3: 368 - 372, 1968.

27. Tyrrell, D. The fatty acid composition of four entomogenous imperfect fungi. Can. J. Microbiol. 15: 818 - 820, 1969.

28. Van Etten, J.L ; Gottlies, D. Biochemical changes during the growth of fungi. II. Ergosterol and fatty acids in Penicillium atrovenetum. J. of Bacteriol. 89: 409 - 414, 1965.

29. Weete, J.D. Lipid Biochemistry of Fungi and Others Organisms. Plenum Press, New York, 1980, 388 pp.

30. Weete, J.D.; Lawer, G.C.; Laseter, J.L. Total Lipid and esters components of Rhizopus arrhinius: Identification and metabolism. Arch. of Biochm. and Biophysics, 155 : 411-419, 1973.

31. Weete, J.D. Lipids in fungal growth and reproduction. In: The Fungal Spore : Morphogenic Controls.G.Turian and H.R. Hohl (eds) Academic Press New York.,1981,p463-485.

32. Yarwood, C.E. Simultaneous self-stimulation and self inhibition of uredospore germination. Mycologia, 48:20-24., 1956. 